\title{
Electrophysiological Interactions of Isomers of Cyclazocine with the Phencyclidine Antagonist Metaphit in Rat Cerebellar Purkinje Neurons
}

\author{
Yun Wang, ${ }^{*}, 1$ Michael R. Palmer, ${ }^{*}$ Robert Freedman, $\dagger \neq$ Kenner C. Rice, $\S$ Ralph A. Lessor, $\S$ Arthur E. \\ Jacobson, $\S$ and Barry J. Hoffer ${ }^{\star}$ \\ Department of *Pharmacology and †Psychiatry, University of Colorado Health Sciences Center, Denver, \\ Colorado 80262, †Medical Research Service, Denver Veterans Administration Medical Center, Denver, Colorado \\ 80220, §Laboratory of Chemistry, Institute of Arthritis, Diabetes, Digestive, and Kidney Diseases, National \\ Institutes of Health, Bethesda, Maryland 20892
}

\begin{abstract}
Metaphit, 1-(1-(3-isothiocyanatophenyl) cyclohexyl) piperidine, an analog of phencyclidine (PCP) has been shown previously to selectively block PCP receptors and to irreversibly antagonize the depressant effect of PCP in cerebellum. In this study, we examined the electrophysiological interactions of metaphit and naloxone with stereoisomers of cyclazocine, an agent known to have analgesic and psychotomimetic activity in behavioral studies, effects that have been ascribed to opiate and PCP receptor activity. $\Lambda$ dose-dependent and reversible slowing of Purkinje neuron discharge was seen with local application of $(+)$ - or $(-)$ cyclazocine. We found that the blockade of $(-)$-cyclazocine effects required both high doses of naloxone and the presence of metaphit, whereas the responses to $(+)$-cyclazocine were blocked by metaphit alone on most cerebellar Purkinje neurons. These findings suggest that the depressant reaction of $(+)$-cyclazocine in cerebellar Purkinje neurons is primarily mediated through PCP receptors. (-)-Cyclazocine responses, on the other hand, appear to be due to activity at both PCP and $k$ opioid receptors.
\end{abstract}

On the basis of physiological and behavioral studies, the existence of multiple opioid receptors was first proposed by Martin and his associates (Gilbert and Martin, 1976; Martin, 1981; Martin et al., 1976). The prototypic opiates, such as morphine, elicit analgesia and sedation via a $\mu$ receptor (Pasternak et al., 1980). While benzomorphans such as cyclazocine and ketocyclazocine also elicit such effects, they show little cross tolerance with morphine and are antagonized by much higher doses of naloxone than are needed to block the effects of morphine (Hutchison et al., 1975; Kosterlitz et al., 1981). On the basis of these and other findings, it was postulated that cyclazocine and ketocyclazocine are antagonists at the $\mu$ receptor and full agonists at a second, $\kappa$, opioid receptor (Martin, 1981).

In addition to these effects, cyclazocine and $N$-allylnormetazocin (SKF-10047) have been shown to elicit dysphoric and psychotomimetic effects in man and delirium in dogs (Jansinski et al., 1968; Keats and Telford, 1964; Martin et al., 1965, 1976; Vaupel, 1983). Since these effects are not mimicked by either morphine or ketocyclazocine, and since they are not antagonized

\footnotetext{
Received Dec. 13, 1985; revised May 29, 1986; accepted June 4, 1986.

Supported in part by USPHS Grants DA 02420 and DA 02702, and by the Robert Lim Foundation.

Correspondence should be addressed to Dr. Barry J. Hoffer, Department of Pharmacology, C-236, University of Colorado Health Sciences Center, $4200 \mathrm{E}$. 9th Avenue, Denver, CO 80262.

Permanent address: Department of Pharmacology, National Defense Medical Center, Taipei, Taiwan, R.O.C.

Copyright $@ 1986$ Society for Neuroscience $0270-6474 / 86 / 113189-08 \$ 02.00 / 0$
}

even by very high doses of naloxone (Vaupel, 1983; Zukin and Zukin, 1983), a third, $\sigma$, receptor has also been postulated. The $\sigma$-mediated behavioral effects of cyclazocine (Brady et al., 1982; Cowan, 1981; Gilbert and Martin, 1976; Martin et al., 1965; Shannon, 1983; Slifer and Balster, 1983) are of particular interest since these are similar to and generalize with the nonsoporific response to the dissociative anesthetic, phencyclidine (PCP) (Herling and Woods, 1981; Teal and Holtzman, 1980; Vaupel, 1983; Vaupel and Jansinski, 1979). Since PCP, likc cyclazocine, is a potent psychotomimetic in man (Bakker and Amini, 1961), further exploration of the similarities between these 2 substances was undertaken. Several electrophysiological studies from our laboratory have provided additional data on the relationship of PCP and cyclazocine. These studies were carried out in rat cerebellum since significant populations of $\kappa$ and PCP receptors are present in this region (Itzhak et al., 1985; Largent et al., 1984; Zukin and Zukin, 1981, 1983; Zukin et al., 1983) and since cerebellar Purkinje neurons can be readily identified during acute recording (Eccles et al., 1967). The local application of cyclazocine or PCP by pressure ejection slowed the discharge of cerebellar Purkinje neurons. While the effects of PCP application were insensitive to naloxone, the cyclazocine responses comprised both a naloxone-sensitive and a naloxoneinsensitive component ( $\mathrm{Kim}$ et al., 1985). However, the observed partial antagonisms of cyclazocine effects were transient and required high doses of naloxone $(>1.0 \mathrm{mg} / \mathrm{kg})$. These data indicated that at least 2 mechanisms may mediate the electrophysiological effects of (-)-cyclazocine in cerebellum. It was suggested that the naloxone-sensitive cyclazocine effects may be mediated via $\kappa /$ opiate receptors since the density of $\mu$ receptors in albino rat cerebellum is extremely low (Antweh and Kuhar, 1977; Hiller et al., 1973; Pert et al., 1976; Snyder et al., 1974), and since the high doses of naloxone used in that study were in the range previously reported to block $\kappa$ mechanisms (Harris, 1980; Iwamoto, 1981; Martin et al., 1976; Romer et al., 1980; Teal and Holtzman, 1980; Zukin and Zukin, 1981). On the other hand, the naloxone-insensitive effects of cyclazocine were phenomenologically similar to those caused by PCP. Indeed, our electrophysiological studies, which suggest that (-)-cyclazocine is the more potent stereoisomer in cerebellum (Kim et al., 1985), are consistent with previous reports that $(-)$-cyclazocine is more potent than the $(+)$ isomer both in discriminative stimulus studies (Shannon, 1982) and in competing for PCP or dexoxadrol binding sites (Mendelsohn et al., 1984; Sethy and McCall, 1984; Zukin, 1982). Even so, it cannot be concluded that the naloxoneinsensitive effect of cyclazocine is mediated by a $\sigma / \mathrm{PCP}$ receptor Inechanism withoul evidence that PCP receptor blockers also antagonize this response. 
A. $\operatorname{crc} 3$ pe

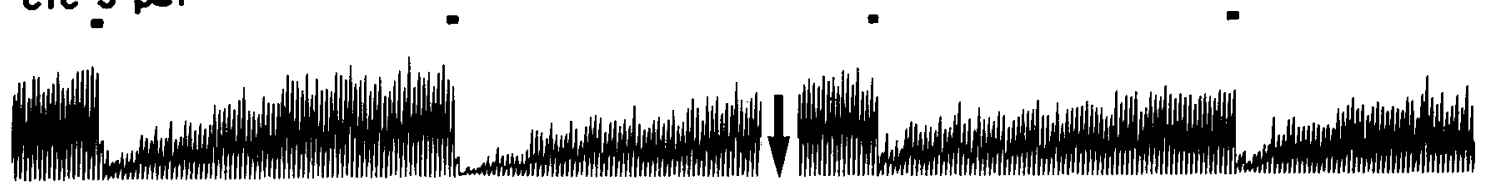

B.
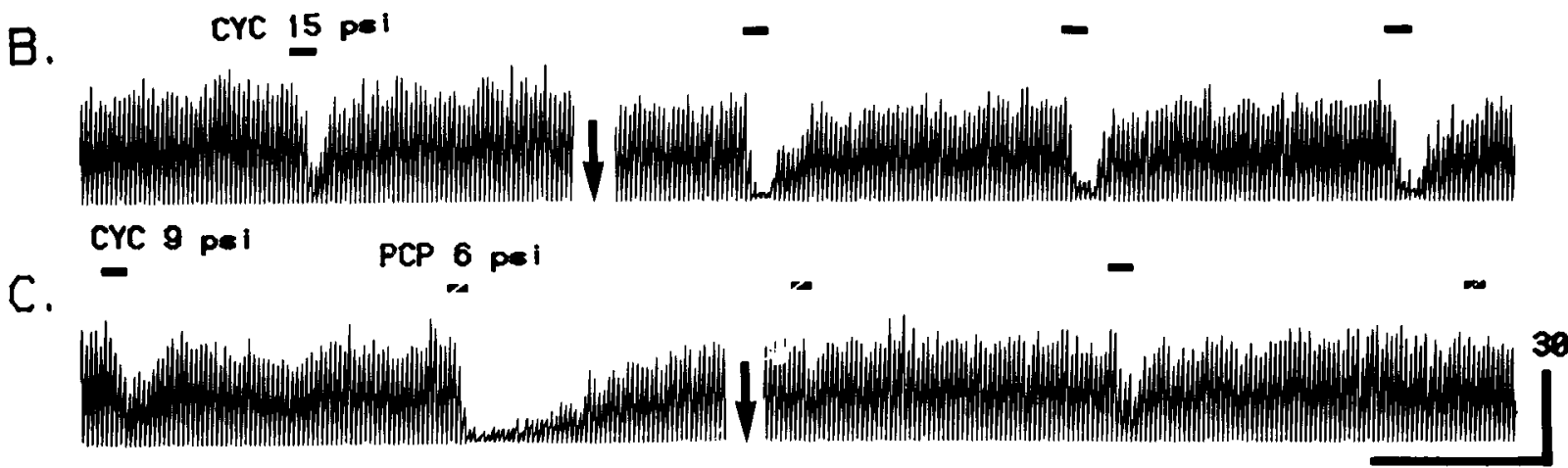

$30 \mathrm{~s}$.

Figure 1. Lack of antagonism of (-)-cyclazocine by locally applied metaphit. Here and in Figures 2-6, (-)-cyclazocine is indicated as CYC. A$C$, Ratemeter records from 3 different Purkinje cells. In each case, the control responses of (-)-cyclazocine (solid line) or PCP (dotted line, cell C) are shown on the left side of the arrow, and the responses after metaphit are shown on the right. Arrows represent local applications of $0.2 \%$ metaphit at 5-10 psi for 30-90 sec. Such applications abolish spontaneous discharge. Recovery of firing usually takes 5-20 min, after which (-)-cyclazocineinduced responses are unaffected $(A-C)$, whereas PCP responses $(C)$ are blocked. In this and all succeeding ratemeter records, the duration of drug ejection is indicated by the bar overlying the trace, and the ejection pressure (in psi) is given by the number after the drug.

We have recently reported that metaphit [1-(1-(3-isothiocyanatophenyl) cyclohexyl) piperidine], which has been found to acylate PCP receptors irreversibly (Rafferty et al., 1985), completely antagonizes the electrophysiological action of PCP in the cerebellum (Wang et al., 1985, 1986a). In the study reported here, we investigated the relative roles of $\mathrm{PCP}$ and $\kappa$ receptor mechanisms in the mediation of the electrophysiological actions of cyclazocine in cerebellum. The interactions of metaphit with $(+)$-cyclazocine and (-)-cyclazocine on cerebellar Purkinje neurons were investigated both before and after the administration of high doses of naloxone. The data reported here suggest that the electrophysiological effects of cyclazocine on cerebellar Purkinje neurons have at least 2 components, one of which is $k /$ opiate-like in that it is sensitive to high doses of naloxone and one of which is PCP-like in that it is sensitive to metaphit.

\section{Materials and Methods}

Male Sprague-Dawley rats (200-350 g) were anesthetized with urethane $(1.25 \mathrm{~g} / \mathrm{kg}$, i.p. $)$, intubated, and placed in a stereotaxic frame. The skull and dura overlying the cerebellum were removed, and the cerebellar surface was covered with $2.0 \%$ agar. The cisterna was opened at the foramen magnum to reduce brain pulsations. Body temperature was monitored with a thermistor probe and maintained at $37^{\circ} \mathrm{C}$ with a heating pad.

Extracellular action potentials were recorded from single cerebellar Purkinje neurons in lobules VI and VII of the cerebellar vermis through the $5 \mathrm{M} \mathrm{NaCl}$-filled barrel of 3 or 4 barrel micropipettes that were constructed as previously described (Palmer et al., 1980). Neuronal activity was filtered, monitored on an oscilloscope, and then converted to constant voltage pulses using a window discriminator. The pulses were integrated over $1 \mathrm{sec}$ epochs by a ratemeter and were displayed on a strip-chart recorder. Cerebellar Purkinje neurons were identified by their characteristic discharge pattern of simple and complex spikes (Eccles et al., 1967).

Drugs were applied from 2 or 3 barrels of the micropipette by pressure ejection as previously described (Palmer et al., 1980). Pressure applications were regulated by a pneumatic valve (1-35 psi), and the timing of drug pulses was controlled by crystal clock circuit. Previous studies have shown that drug administration by this technique is reproducible and is linearly related to pressure and time of ejection (McCaman et al., 1977). To be considered valid, all responses to pressure-ejected agonists were required to show dose dependency, reversibility and reproducibility. Previously described controls were used to test for local anesthesia, $\mathrm{pH}$ effects, drug specificity, and pressure artifacts (Palmer, 1982). The drug solutions that were pressure ejected were $1 \mathrm{~mm}(-)$ cyclazocine, $1 \mathrm{~mm}(+)$-cyclazocine, $1 \mathrm{~mm}$ phencyclidine [1-(1-phenylcyclohexyl) piperidine $\mathrm{HCl}$; $\mathrm{PCP}$; $0.5 \mathrm{~mm}$ naloxone $\mathrm{HCl}$, and $5.5 \mathrm{~mm}$ metaphit. All drugs used in local applications were made up in $165 \mathrm{~mm}$ $\mathrm{NaCl}, \mathrm{pH} 7.0$, except as noted. Naloxone $\mathrm{HCl}$ (Narcan; Dupont Pharmaceuticals) was also administered subcutaneously (s.c.) or intraperitoneally (i.p.) at $1,2,5$, or $10 \mathrm{mg} / \mathrm{kg}$.

Ratemeter records were analyzed for changes in neuronal discharge caused by local drug application as previously described (Palmer and Hoffer, 1980). The data were digitized and quantified by computer analysis to indicate the percentage of depression or excitation of neuronal activity caused by drug application. Previous reports from our laboratory have evaluated the validity of this analytic approach to quantitate responses of neurons to microadministration of drugs (Freedman et al., 1975; Palmer et al., 1980). Using these techniques, drug responses can be evaluated independently of changes in background discharge, and apparent antagonism due to changes in release of drug from the pipette can be minimized (Freedman et al., 1975).

\section{Results}

Local application of $(-)$-cyclazocine, administered by pressure ejection, reversibly slowed Purkinje neuron discharge (Fig. 1, $A-C$, left-hand side of arrows). Metaphit, when applied locally (vertical arrows) with ejection parameters that readily block PCP-induced responses (Wang et al., 1985, 1986a) did not antagonize (-)-cyclazocine-induced inhibitions of most Purkinje neurons. Thus, the (-)-cyclazocine-elicited depression from 12 of 14 neurons was unaltered by $30-90 \mathrm{sec}$ applications of metaphit (Table 1). There was less than a 50\% antagonism of (-)-cyclazocine effects on the remaining 2 cells. PCP applied alternately with CYC to 3 neurons produced effects that were completely blocked by doses of metaphit that left (-)-cyclazocine responses unchanged (Fig. 1C).

In order to further differentiate between $\mathrm{PCP}$ and $\kappa$ receptor- 

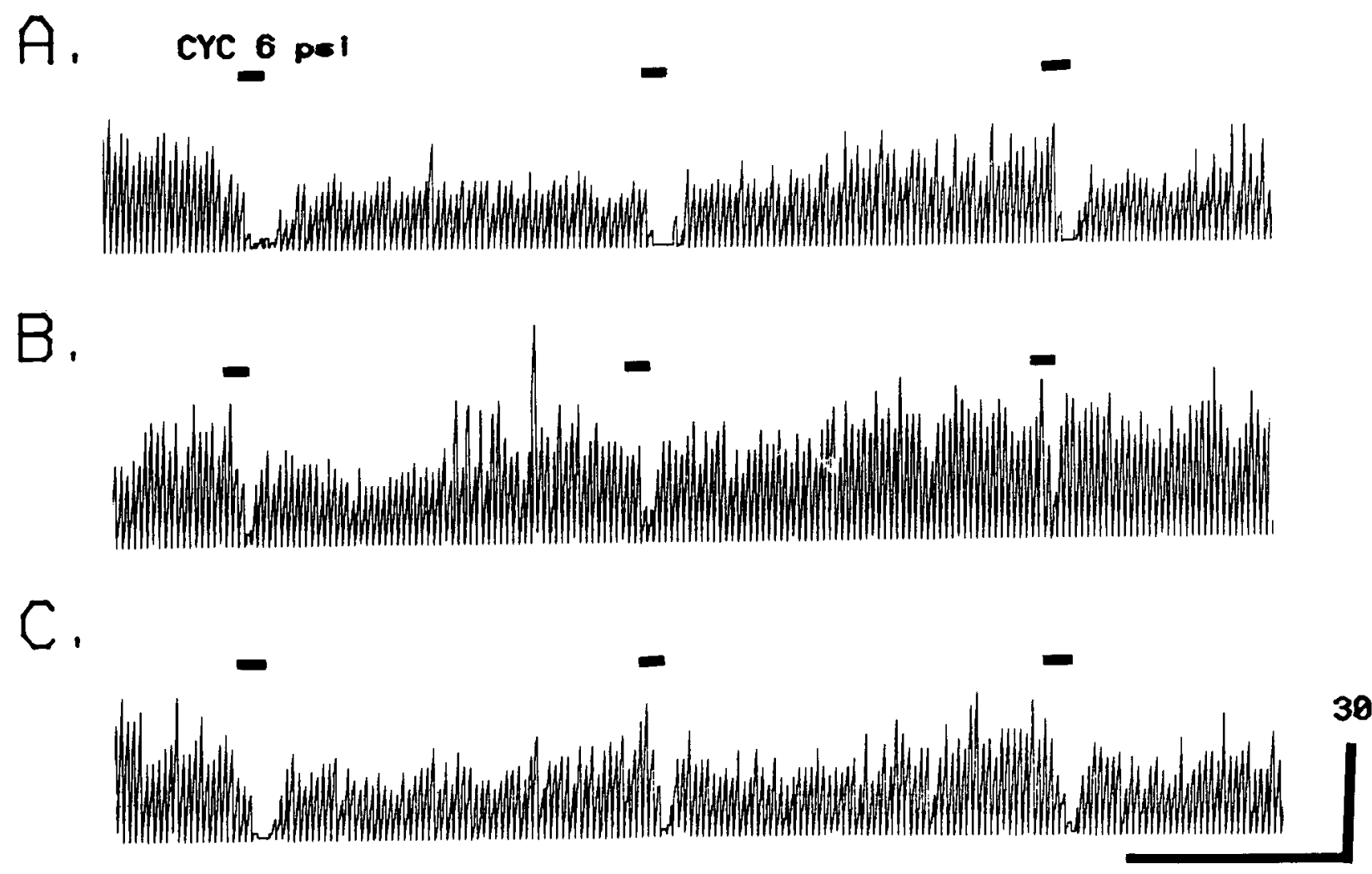

$38 \mathrm{~S}$.

Figure 2. Weak and transient blockade of (-)-cyclazocine by i.p. naloxone. The control responses $(A)$ show (-)-cyclazocine-induced depressions of one $\mathrm{P}$ neuron. After parenteral naloxone application $(B$ and $C, 6 \mathrm{mg} / \mathrm{kg}, \mathrm{i} . \mathrm{p}),.(-)$-cyclazocine responses are only partially and transiently antagonized.

mediated effects, the interaction of $(-)$-cyclazocine with high doses of naloxone was studied. Naloxone, when administered at doses of $6-10 \mathrm{mg} / \mathrm{kg}$, i.p. (Fig. $2, B, C$ ) or subcutaneously (Fig. 3, $B, C$ ), or when applied locally for several minutes by pressure ejection, caused weak and transient antagonisms of $(-)$ cyclazocine-induced inhibitions in 4 of 9 neurons. The cyclazocine responses were reduced by less than $50 \%$ and the antagonisms to systemic naloxone lasted less than 5 min (Figs. 2, 3). The effects of $(-)$-cyclazocine on the additional 5 neurons were not antagonized by naloxone (Table 1 ).

Although the electrophysiological effects of $(-)$-cyclazocine are not completely blocked by treatment with either metaphit or naloxone alone, the observed (-)-cyclazocine-induced depressions of neuronal activity may be mediated partially by a naloxone-sensitive mechanism and partially by activation of a metaphit-sensitive site. If this is true, then combinations of these 2 receptor antagonists might be expected to block the effects of locally applied (-)-cyclazocine. Two different proto-

Table 1. Blockade of (-)-cyclazocine by metaphit and/or naloxone in cerebellar Purkinje neurons

\begin{tabular}{lcll} 
& \multicolumn{3}{l}{ Blockade } \\
\cline { 2 - 4 } Antagonist & None & $\begin{array}{l}\text { Weak } \\
(<50 \%)\end{array}$ & $\begin{array}{l}\text { Strong } \\
(>90 \%)\end{array}$ \\
\hline Metaphit & $12^{a}$ & 2 & 0 \\
Naloxone & 5 & 4 & 0 \\
Metaphit + naloxone & 2 & 0 & 10 \\
\hline
\end{tabular}

${ }^{a}$ Number of neurons. cols were used to test this conjecture: (1) locally applied metaphit after parenteral naloxone and (2) locally applied naloxone after local metaphit. The combined administration of naloxone and metaphit completely antagonized the effects of locally applied (-)-cyclazocine on 10 of 12 Purkinje neurons tested (Table 1). Two examples of the blockade using the first protocol are shown in Figure 4. Parenteral naloxone, $8 \mathrm{mg} / \mathrm{kg}$, was given prior to the leftmost ratemeter trace in each case. Although $(-)$-cyclazocine still produced a potent effect after the naloxone treatment, this response was blocked after subsequent treatment with metaphit (Fig. 4, right-hand side of arrows).

One problem with first protocol is that both the high-dose parenteral naloxone and metaphit applications are quite long lasting. Thus, recovery of agonist effect cannot be easily demonstrated. Hence, the second protocol, using locally applied naloxone, was also used (Figs. 5 and 6). Following local applications of metaphit (vertical arrows), pressure-ejected naloxone completely and reversibly blocked the (-)-cyclazocine-induced depressions of Purkinje neurons. These drug interactions were reproducible on each neuron studied (Figs. 5, C, D, and $6, D$, $E)$.

A markedly different antagonist sensitivity was observed for the $(+)$-isomer of cyclazocine. Although totally insensitive to naloxone, the depressant actions of $(+)$-cyclazocine were completely antagonized by metaphit alonc in 11 of 14 ncurons testcd (Fig. 7, $A-D$; Table 2). The blockade of the depressant effects of $(+)$-cyclazocine on cerebellar Purkinje neurons began after the application of metaphit and did not recover during the $1 \mathrm{hr}$ testing period used for each cell. The $(+)$-cyclazocine induced depressions from 3 of 14 Purkinje neurons were insensitive to the metaphit treatment (Fig. $7 E$ ). 

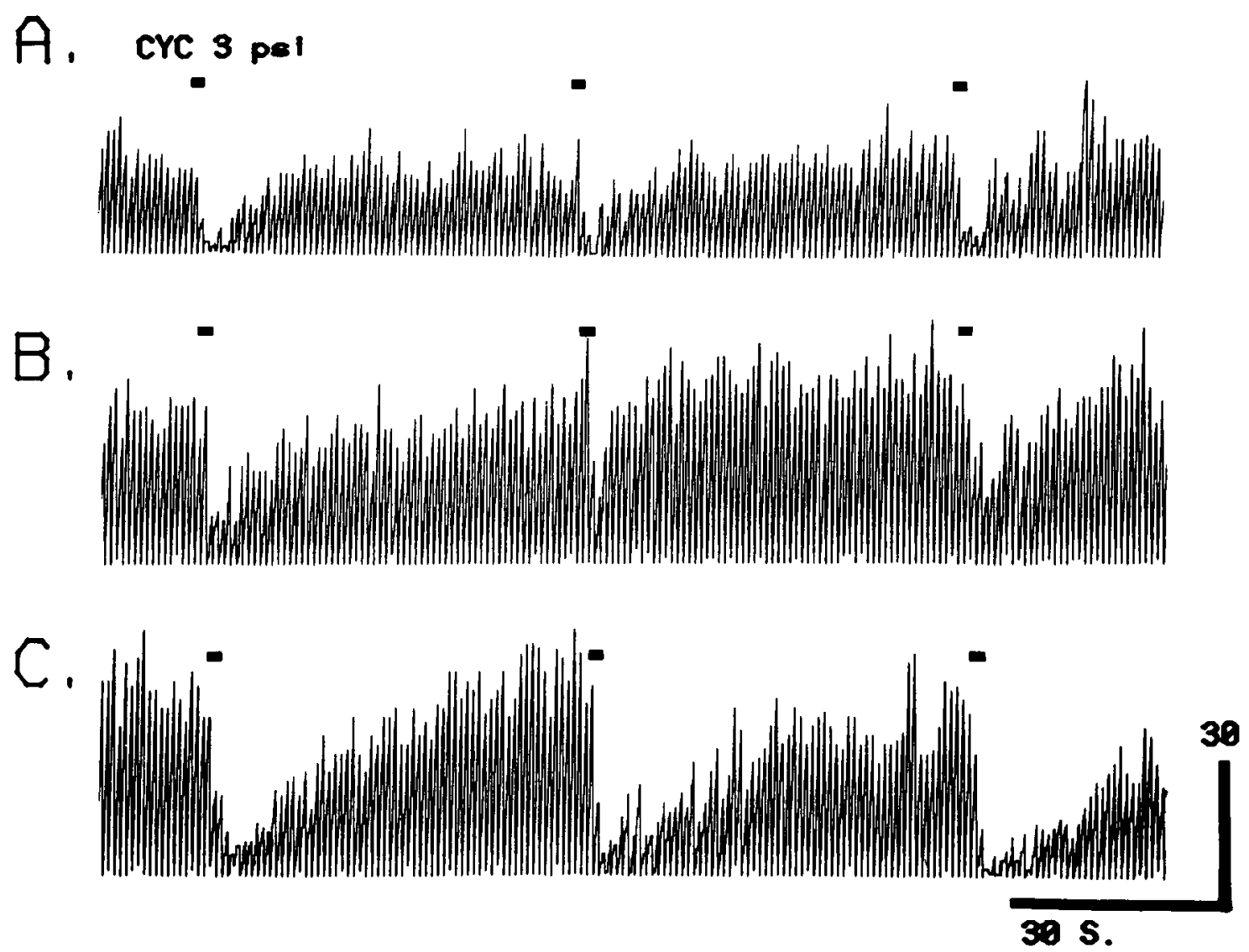

Figure 3. Weak and transient blockade of (-)-cyclazocine by s.c. naloxone. $A$, Control (-)-cyclazocine responses. $B$ and $C$, After s.c. injection of nalaxone, $10 \mathrm{mg} / \mathrm{kg},(-)$-cyclazocine responses were partially and transiently antagonized.

\section{Discussion}

Similar to a previous study from this laboratory (Kim et al., 1985), we found that responses to (-)-cyclazocine were partially, although transiently, antagonized by high doses of the opiate antagonist, naloxone. We also previously reported that the naloxone-insensitive effects of $(-)$-cyclazocine in cerebellum were similar to those caused by PCP in that brain area. In the present investigation, we also studied the sensitivity of cyclazocineinduced responses to metaphit, an isothiocyanate derivative of PCP that has been reported to form covalent bonds with PCP receptors selectively (Rafferty et al., 1985). While the electrophysiological effects of the $(+)$ isomer of cyclazocine were blocked by local metaphit application, responses to $(-)$-cyclazocine were either unaltered or were only partially antagonized by this putative irreversible PCP receptor antagonist. These data could

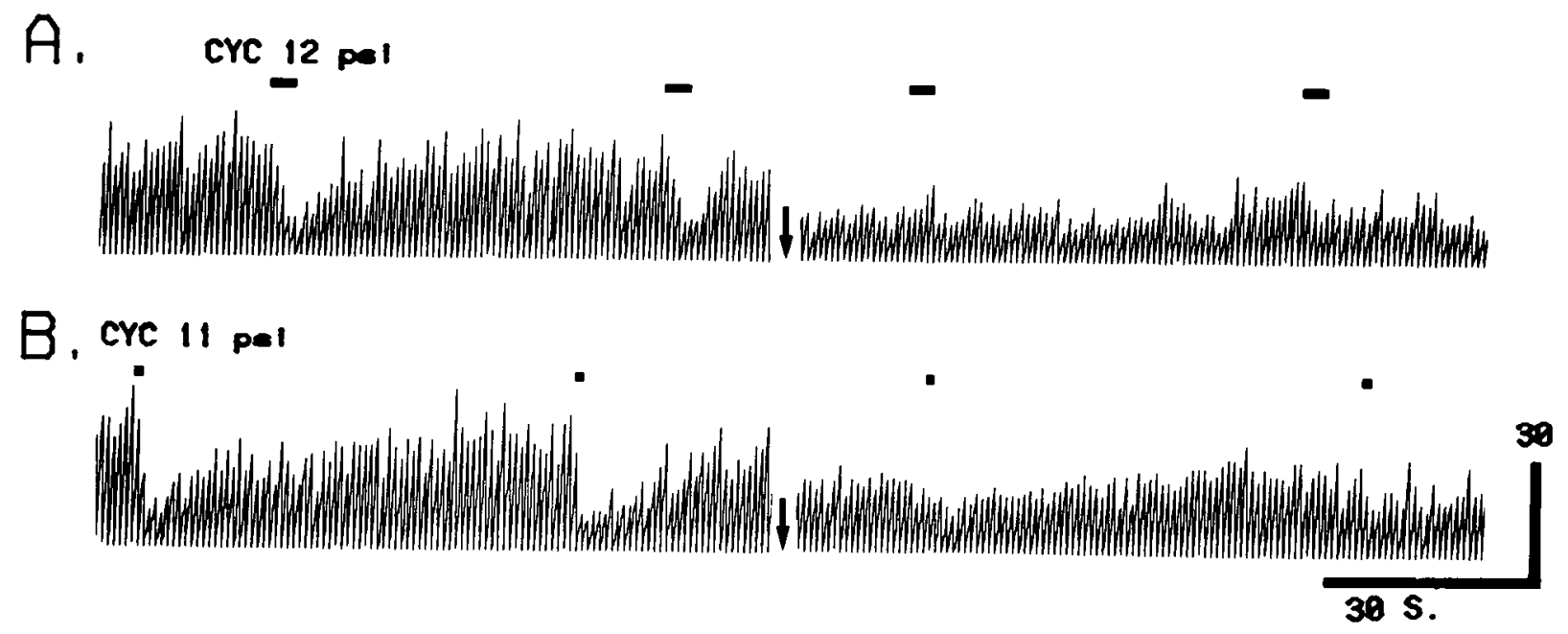

Figure 4. Blockade of cyclazocine-induced depression by local metaphit after parenteral naloxone. P cells $(A$ and $B)$ from 2 different animals are illustrated. The control records (left of arrow) show responses to (-)-cyclazocine after parenteral naloxone. Following local metaphit application (vertical arrow, 5-10 psi, $45 \mathrm{sec}$ ) and recovery of discharge, responses to (-)-cyclazocine (right of arrow) were completely antagonized. 
A.

MLOXONE $\left(5 \times 10^{-4} \mathrm{M}\right) 4$ pal

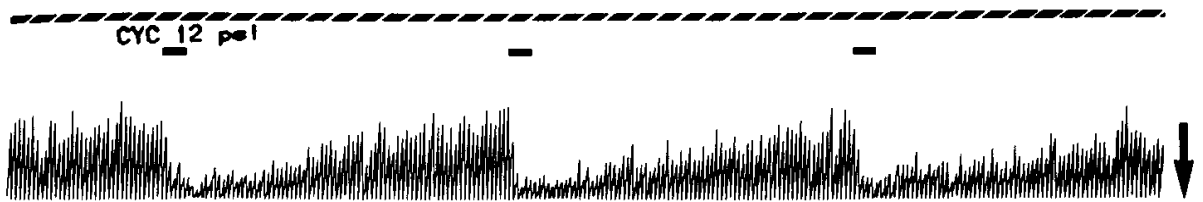

B.

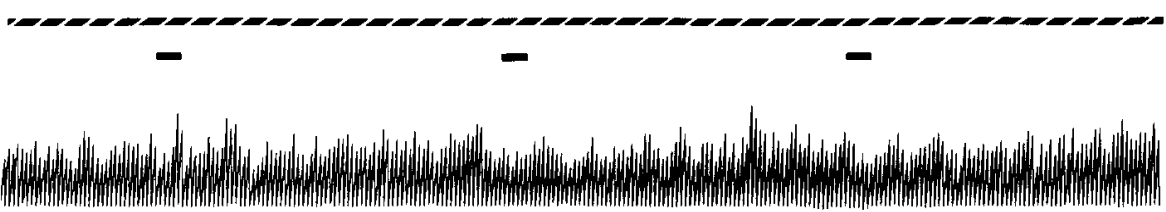

C.

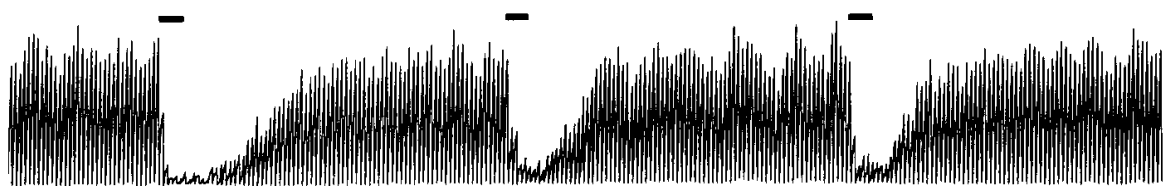

D.

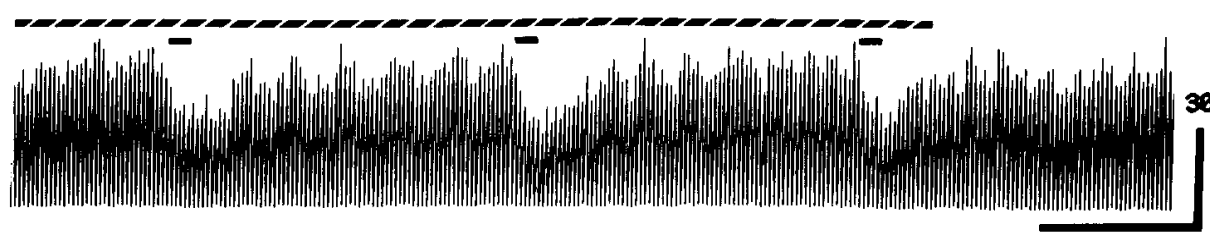

$30 \mathrm{~s}$.

A.

MULOXOE $\left(6 \times 10^{-1} M\right) \quad 4$ pol

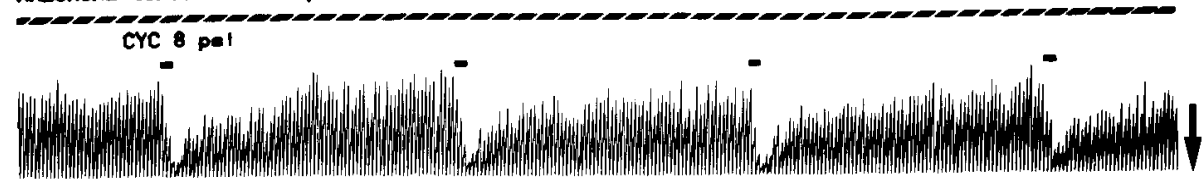

B.

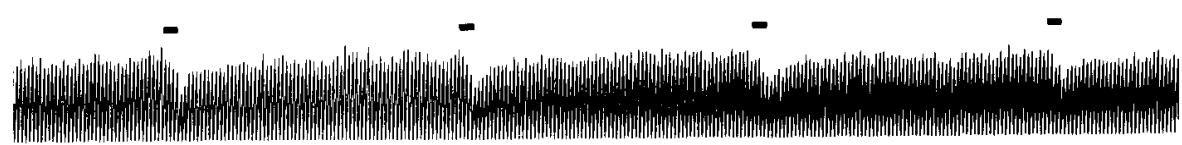

C.

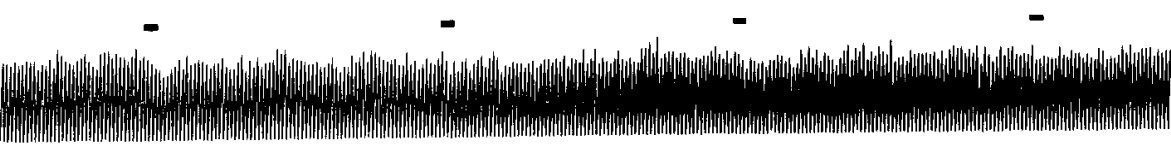

D.

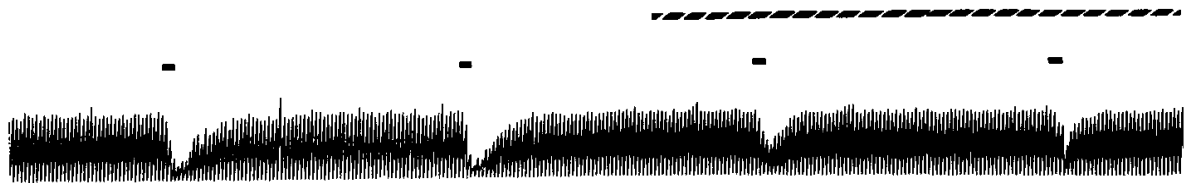

E.

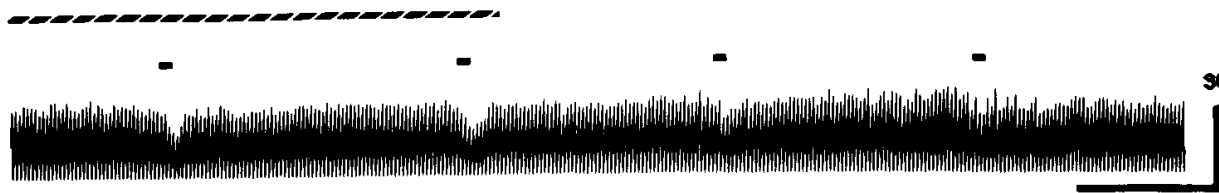

298
Figure 5. After, but not before, local metaphit application, (-)-cyclazocine was reversibly blocked by local naloxone. Control responses $(A)$ represent (-)-cyclazocine effects during local naloxone application. After applying metaphit (vertical arrow at end of $A, 18 \mathrm{psi}, 180 \mathrm{sec}$ ), (-)-cyclazocine effects were gradually antagonized by a second application of naloxone $(B)$. Discontinuing naloxone $(C)$ permits recovery of $(-)$-cyclazocine effects. Application of naloxone for a third time again blocks $(-)$-cyclazocine-induced slowing $(D)$.
Figure 6. Reversible blockade of $(-)$-cyclazocine by local naloxone in the presence of metaphit. $A$, Control $(-)$-cyclazocine responses in the presence of naloxone. $B$, and $C$, After local metaphit application (vertical arrow at end of $A, 15$ psi, 260 sec), (-)-cyclazocine's depressant effects gradually disappeared. $D$, Discontinuing naloxone led to the recovery of (-)cyclazocine responses. $D$ and $E$, Second application of naloxone locally again causes blockade of (-)-cyclazocine-induced depressions. 
A.

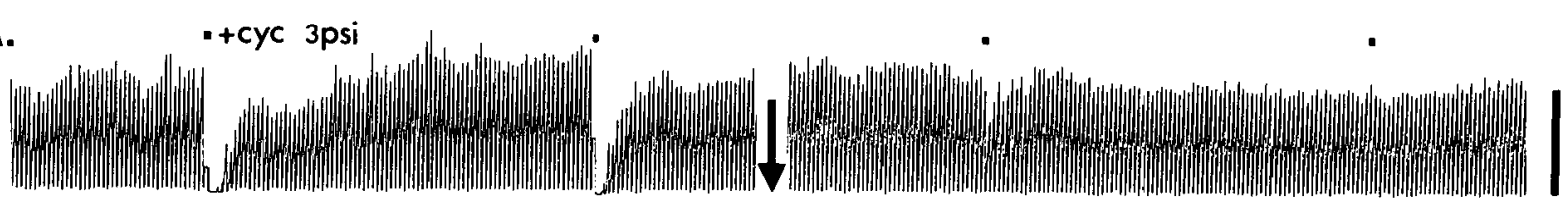

B.

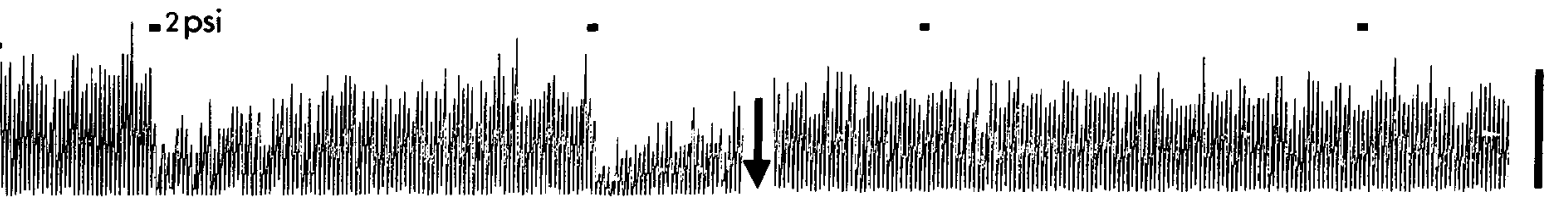

C. $-4 p s i$

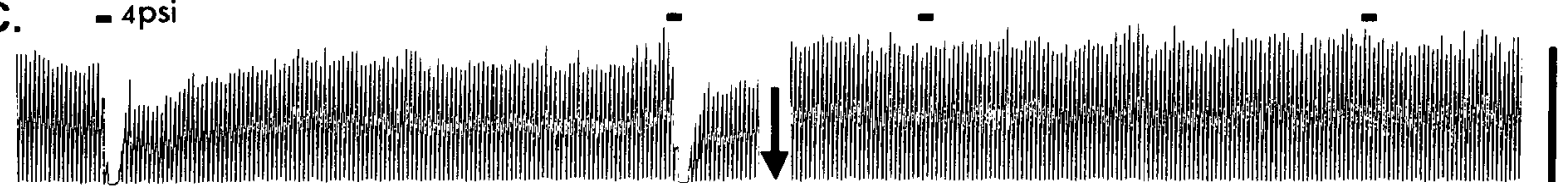

D.

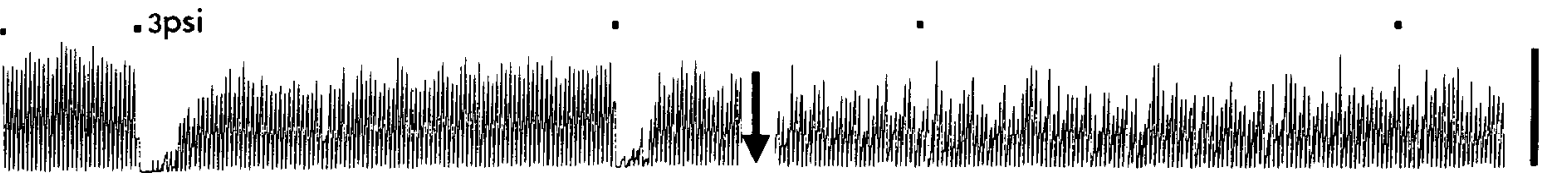

E.
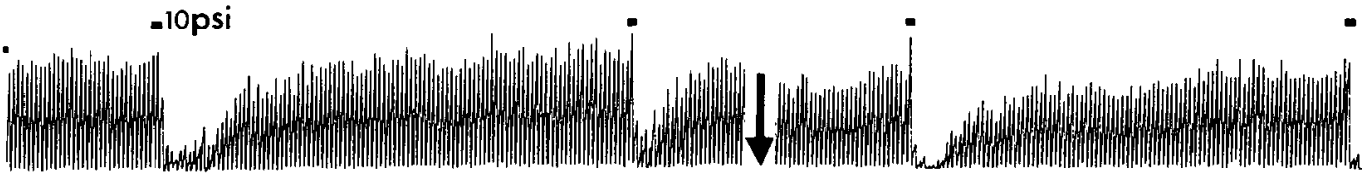

-

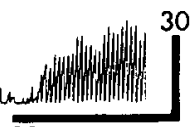

Figure 7. Interactions of $(+)$-cyclazocine $(+\mathrm{cyc})$, and metaphit on cerebellar $\mathrm{P}$ cells. $A-E$, Ratemeter records from 5 different cells. Left-most traces illustrate control $(+)$-cyclazocine-induced depressions. After application of metaphit (vertical arrows), $(+)$-cyclazocinc was again tested in the right-most traces. Note complete antagonism in cells $A-D$ and no blockade in cell $E$.

suggest that (+)- but not (-)-cyclazocine had a PCP-like mechanism of action. This is consistent with the behavioral observations (Solomon et al., 1981) that $(+)$ - but not $(-)$-cyclazocine has discriminative properties in rhesus monkeys that are similar to ketamine, a PCP analog. However, (-)-cyclazocine does cause PCP-like stimulus effects in other animal species, such as rats (Shannon, 1982), pigeons (McMillan, 1982), and squirrel monkeys (Holtzman, 1982). Indeed, the effects of (-)-cyclazocine could be completely antagonized in this study by the concomitant administration of both metaphit and a high dose of naloxone.

Even though (-)-cyclazocine-induced depressions of Purkinje neurons were not blocked by either naloxone or metaphit alone, the observation that these responses were blocked by high doses of naloxone in the presence of metaphit suggests that $(-)$-cyclazocine interacts with at least two classes of receptors in cerebellum at the doses studied. The metaphit-sensitive component of the response may represent actions of cyclazocine at the $\mathrm{PCP} / \sigma$ site. Not only has metaphit been reported to bind to PCP receptors in the brain irreversibly (Rafferty et al., 1985), but we have also previously shown that metaphit specifically and irreversibly blocks the electrophysiological effects of PCP in the cerebellum (Wang et al., 1986a) and hippocampus (Wang et al., $1986 \mathrm{~b})$. Furthermore, in contrast to findings on the hippocampus, where only $60 \%$ of the PCP receptors are metaphit sensitive, our preliminary neurochemical evidence indicates that nearly $100 \%$ of the PCP binding sites in cerebellum are blocked after treatment with $10 \mu \mathrm{M}$ metaphit (Wang et al., 1985). Thus, the actions of both isomers of cyclazocine appear to involve this metaphit-sensitive PCP mechanism in the cerebellum. The interactions of cyclazocine with PCP mechanisms in other brain regions, such as hippocampus, may prove more complex.

Our observation that the electrophysiological effects of $(-)$ cyclazocine in the cerebellum are partially mediated by a naloxone-sensitive mechanism is consistent with the behavioral findings of Teal and Holtzman (1980). They reported that the effects of cyclazocine in the rat discriminative stimulus assay are only partially reversed by naltrexone, another opiate antagonist. Furthermore, (-)-cyclazocine is over 15 times more potent than morphine as an analgesic in the phenylquinone (PPQ) antinociceptive assay in mice. Similar to the data reported here, the analgesic action of (-)-cyclazocine can be blocked only by high doses of naloxone in the PPQ assay. In contrast, cyclazocine has no analgesic effect in the PPQ assay at doses up to $1.0 \mathrm{mg} /$ $\mathrm{kg}$, which is more than 70 times greater than that of $(-)$-cyclazocine in this assay. It is known from binding studies that (-)cyclazocine has high affinity for both $\mu$ and $\kappa$ opioid receptors as well as for PCP receptors (Chang et al., 1980; Zukin and Zukin, 1981). However, there are few $\mu$ receptors in cerebellum (Kuhar et al., 1973), and the doses of naloxone required to block $\kappa$ receptors are much higher than those needed for $\mu$ antagonism

Table 2. Blockade of $(+)$-cyclazocine by metaphit in cerebellar Purkinje neurons

Blockade

\begin{tabular}{llll}
\cline { 2 - 4 } Antagonist & None & $\begin{array}{l}\text { Weak } \\
(<50 \%)\end{array}$ & $\begin{array}{l}\text { Strong } \\
(>90 \%)\end{array}$ \\
\hline Metaphit & $3^{a}$ & 0 & 11 \\
\hline
\end{tabular}

a Number of neurons. 
(Kosterlitz et al., 1981). Thus, the component of the (-)-cyclazocine response in cerebellum that is sensitive to high doses of naloxone might represent a $k$ opiate receptor interaction.

Our observation that both opiate and PCP receptors must be inactivated in order to antagonize the effects of $(-)$-cyclazocine in the cerebellum suggests that both $\kappa$ and PCP mechanisms are involved in the Purkinje neuron responses to $(-)$-cyclazocine. Thus, the blockade of either receptor type alone is insufficient for antagonizing these responses. Indeed, Slifer and Balster (1983) have argued that the apparent stereoselectivity for (-)-cyclazocine in many studies has been due to contamination of the results with the activation of $k$ receptors or with other naloxonesensitive opiate mechanisms. Further studies will be required to determine if there are complex interactions between $\kappa$ and $\mathrm{PCP} / \sigma$ mechanisms in addition, perhaps, to influences of other neurotransmitters in this brain area that acutely compensate for the pharmacological antagonism of either receptor site.

In conclusion, our data suggest that while $(-)$-cyclazocine has activity at both PCP and $\kappa$ mechanisms in cerebellum, $(+)$ cyclazocine's depressant effects are probably mediated primarily through activation of the metaphit-sensitive PCP receptor. Determination of the extent, however, to which such interactions in cerebellum or elsewhere underlie the behavioral actions of $(+)$ - and (-)-cyclazocine awaits further pharmacological experiments involving recordings in freely moving, unanesthetized animals.

\section{References}

Antweh, S. F., and M. J. Kuhar (1977) Autoradiographic localization of opiate receptors in rat brain. I. Spinal cord and lower medulla. Brain Res. 124: 53-67.

Bakker, M. D., and F. B. Amini (1961) Observations on the psychotomimetic effects of sernyl. Comp. Psychiatr. 2: 269-280.

Brady, K. T., R. L. Balster, and E. L. May (1982) Stereoisomers of $\mathrm{N}$-allylnormetazocine: Phencyclidine-like behavioral effects in squirrel monkeys and rats. Science 215: 178-180.

Chang, K.-J., E. Hazum, and P. Cuatrecasas (1980) Possible role of distinct morphine and enkephalin receptors in mediating actions of benzomorphan drugs (putative kappa and sigma agonists). Proc. Natl. Acad. Sci. USA 77: 4469-4473.

Cowan, A. (1981) III. Simple in vivo tests that differentiate prototype agonists at opiate receptors. Life Sci. 28: 1559-1570.

Dunwiddie, T., A. Mueller, M. Palmer, J. Stewart, and B. Hoffer (1980) Electrophysiological interactions of enkephalins with neuronal circuitry in the rat hippocampus. I. Effects on pyramidal cell activity. Brain Res. 184: 311-330.

Eccles, J. C., M. Ito, and J. Szentagothai (1967) The Cerebellum as Neuronal Machine, Springer-Verlag, New York.

Freedman, R., B. J. Hoffer, and D. J. Woodward (1975) A quantitative microiontophoretic analysis of the responses of central neurons to noradrenaline: Interactions with cobalt, manganese, verapamil, and dichloroisoprenaline. Br. J. Pharmacol. 54: 529-539.

Gilbert, P. E., and W. R. Martin (1976) The effects of morphine- and nalorphine-like drugs in the non-dependent, morphine-dependent and cyclazocine-dependent chronic spinal dog. J. Pharmacol. Exp. Ther. 198: 66-82.

Harris, R. A. (1980) Interactions between narcotic agonists, partial agonists and antagonists evaluated by schedule-controlled behavior. J. Pharmacol. Exp. Ther. 213: 497-503.

Herling, S., and J. H. Woods (1981) Discriminative stimulus effects of narcotics: Evidence for multiple receptor-mediated action. Life Sci. 28: 1571-1584.

Hiller, J. M., J. Pearson, and E. J. Simon (1973) Distribution of stereospecific binding of potent narcotic analgesic etorphine in human brain-Predominance in limbic system. Res. Commun. Pathol. Pharmacol. 6: 1052-1062.

Holtzman, S. G. (1982) Phencyclidine-like discriminative stimulus properties of opioids in the squirrel monkey. Psychopharmacology 77: 295-300.

Hutchinson, M., H. W. Kosterlitz, F. M. Leslie, A. A. Waterfield, and L. Terenius (1975) Assessment in guinea-pig ileum and mouse vas deferens of benzomorphans which have strong antinociceptive activ- ity but do not substitute for morphine in the dependent monkey. $\mathrm{Br}$. J. Pharmacol. 55: 541-546.

Itzhak, Y., J. M. Hiller, and E. J. Simon (1985) Characterization of spccific binding sites for [H3]-(d)-N-allylnormetazocine in rat brain membranes. Mol. Pharmacol. 27: 46-52.

Iwamoto, E. T. (1981) Locomotor activity and antinociception after putative mu, kappa and sigma opioid receptor agonists in the rat: Influence of dopaminergic agonists and antagonists. J. Pharmacol. Exp. Ther. 217: 451-460.

Jansinski, D. R., W. R. Martin, and J. D. Sapira (1968) Antagonism of the subjective, behavioral, pupillary and respiratory depressant effects of cyclazocine by naloxone. Clin. Pharmacol. Ther. 9: 215222.

Keats, A. S., and J. Telford (1964) Narcotic antagonists as analgesics. Clinical aspects. In Molecular Modification in Drug Design, Advances in Chemistry, Series 45, R. F. Gould, ed., pp. 170-176.

Kim, M., K. Pang, R. Freedman, and M. R. Palmer (1985) Electrophysiological effects of cyclazocine on rat cercbellar Purkinje ncurons: Comparison with phencyclidine. Alcohol Drug Res. 6: 23-36.

Kosterlitz, H. W., S. J. Paterson, and L. E. Robson (1981) Characterization of the $\kappa$-subtype of the opiate receptors in guinea-pig brain. Br. J. Pharmacol. 73: 939-949.

Kuhar, M. J., C. B. Pert, and S. H. Snyder (1973) Regional distribution of opiate binding in monkey and human brain. Nature 245:447-451.

Largent, B. L., A. L. Gundlach, and S. H. Snyder (1984) Psychotomimetic opiate receptors labeled and visualized with (+)-[H3]-3-(3hydroxyphenyl)-N-(1-propyl) piperidine. Proc. Natl. Acad. Sci. USA 81: 4983-4987.

Martin, W. R. (1981) Multiple opioid receptors, a little about their history and some implications related to evolution. Life Sci. 28: 15471554.

Martin, W. R., H. F. Fraser, C. W. Gorodetzky, and D. E. Rosenberg (1965) Studies of the dependence-producing potential of the narcotic antagonist 2-cyclopropyl methyl-2-hydroxyl-5,9,-dimethyl-6,7,-benzomorphan (cyclazocine, WIN-20, 740, ARC 11-C-3). J. Pharmacol. Exp. Ther. 150:426-436.

Martin, W. R., C. G. Eades, and P. E. Gilbert (1976) The effects of morphine- and morphine-like drugs in the non-dependent and morphine-dependent chronic spinal dog. J. Pharmacol. Exp. Ther. 197: $517-532$

McCaman, R. E., D. G. McKenna, and J. K. Ono (1977) A pressure ejection system for intracellular and extracellular ejections of picoliter volumes. Brain Res. 136: 141-147.

McMillan, D. E. (1982) Generalization of the discriminative stimulus properties of phencyclidine to other drugs in the pigeon using color tracking under second order schedules. Psychopharmacology 78: 131134.

Mendelsohn, L. G., G. A. Kerchner, V. Kalra, D. M. Zimmerman, and J. D. Leander (1984) Phencyclidine receptors in rat brain cortex. Biochem. Pharmacol. 33: 3529-3535.

Palmer, M. R. (1982) Micro pressure-ejection: A complementary technique to microiontophoresis for neuropharmacological studies in the mammalian central nervous system. J. Electrophysiol. Tech. 9: 123139.

Palmer, M. R., and B. J. Hoffer (1980) Catecholamine modulation of enkephalin-induced electrophysiological responses in cerebral cortex. 213: 205-215

Palmer, M. R., S. M. Wuerthele, and B. J. Hoffer (1980) Physical and physiological characteristics of micropressure ejection of drugs from multibarreled pipettes. Neuropharmacology 19: 931-938.

Pasternak, G. W., S. R. Childers, and S. H. Snyder (1980) Opiate analgesia: Evidence for mediation by a subpopulation of opiate receptors. Science 208: 514-516.

Pert, C. B., M. J. Kuhar, and S. H. Snyder (1976) Opiate receptor: Autoradiographic localization in rat brain. Proc. Natl. Acad. Sci. USA 73: 3729-3733.

Rafferty, M. F., M. Mattson, A. E. Jackson, and K. C. Rice (1985) A specific acylating agent for the [H3] phencyclidine receptors in rat brain. FEBS Lett. 181: 318-322.

Romer, D., H. Buscher, R. C. Hill, R. Maurer, T. J. Petcher, H. B. A. Welle, H. C. C. K. Bankel, and A. M. Akkerman (1980) Bremazocine: A potent, long-acting opiate kappa-agonist. Life Sci. 27: $971-$ 978.

Sethy, V. H., and J. M. McCall (1984) High-affinity ( $\left.{ }^{3} \mathrm{H}\right)$-dexoxadrol binding to rat brain membranes. Drug Dev. Res. 4: 635-645. 
Shannon, H. E. (1982) Pharmacological analysis of the phencyclidinelike discriminative stimulus properties of narcotic derivatives in rats. J. Pharmacol. Exp. Ther. 222: 146-151.

Shannon, H. E. (1983) Discriminative stimulus effects of phencyclidine: Structure-activity relationships. In Phencyclidine and Related Arycyclohexylamines: Present and Future Application, J. M. Kamenka, E. F. Domino, and P. Geneste, eds., pp. 311-335, NPP Press, Ann Arbor, MI.

Slifer, B. L., and R. L. Balster (1983) Reinforcing properties of stereoisomers of the putative sigma agonists $\mathrm{N}$-allylnormetazocine and cyclazocine in rhesus monkeys. J. Pharmacol. Exp. Ther. 225: 522528.

Snyder, S. H., C. B. Pert, and G. W. Pasternak (1974) The opiate receptor. Ann. Int. Med. 81: 534-540.

Solomon, R. E., S. Herling, and J. H. Woods (1981) Ketamine-like discriminative characteristics of the stereoisomers of metazocine, cyclazocine, and SKF-10,047 in rhesus monkeys, In Advances in Endogenous and Exogenous Opioids, pp. 484-486, Kodansha, Tokyo.

Teal, J. J., and S. G. Holtzman (1980) Discriminative stimulus effects of cyclazocine in rat. J. Pharmacol. Exp. Ther. 212: 368-379.

Vaupel, D. B. (1983) Phencyclidine studies in the dog: Pharmacology of PCP, profiles of eight analogues abused by man and the similarity of PCP to the opioid NAMA (N-allylnormetazocin or SKF-10,047) In Phencyclidine and Related Arycyclohexylamines: Present and $\mathrm{Fu}$ ture Application, J. M. Kamenka, E. F. Domino, and P. Geneste, eds., pp. 347-367, NPP Press, Ann Arbor, MI.

Vaupel, D. B., and D. R. Jansinski (1979) Acute single dose effects of phencyclidine (PCP) in the dog. Fed. Proc. 38: 435.

Wang, Y., M. R. Palmer, R. Freedman, M. Mattson, R. Lessor, M. Rafferty, K. Rice, A. Jacobson, and B. J. Hoffer (1985) Electro- physiological and biochemical study of the antagonism of PCP action by metaphit in rat cerebellar Purkinje neurons. Soc. Neurosci. Abstr. 910.

Wang, Y., M. R. Palmer, R. Freedman, B. J. Hoffer, M. Mattson, R. A. Lessor, M. F. Rafferty, K. C. Rice, and A. E. Jacobson (1986a) Antagonism of phencyclidine action by metaphit in rat cerebellar Purkinje neurons: An electrophysiological study. Proc. Natl. Acad. Sci. USA 83: 2722-2727.

Wang, Y., K. Pang, A. E. Jacobson, K. C. Rice, and B. J. Hoffer (1986b) Interactions of phencyclidine with hippocampal circuitry: Evidence for neuronal heterogeneity. Pharmacol. Biochem. Behav. 24: 14031407.

Zukin, S. R. (1982) Differing stereospecificities distinguish opiate receptor subtypes. Life Sci. 31: 1307-1310.

Zukin, R. S., and S. R. Zukin (1981) Demonstration of [H3] cyclazocine binding to multiple opiate receptor sites. Mol. Pharmacol. 20. 246-254.

Zukin, R. S., and S. R. Zukin (1983) A common receptor for phencyclidine and the sigma receptor. In Phencyclidine and Related Arylcyclohexylamines: Present and Future Application, J. M. Kamenka, E. F. Domino, and P. Geneste, eds., pp. 107-124, NPP Press, Ann Arbor, MI.

Zukin, S. R, M. L. Fitz-Syage, R. Nichtenhauser, and R. S. Zukin (1983) Specific binding of [ $\left.{ }^{3}\right] \mathrm{H}$-phencyclidine in rat central nervous tissue: Further characterization and technical considerations. Brain Res. 258 277-284.

Zukin, S. R., K. T. Brady, B. L. Slifer, and R. L. Balster (1984) Behavioral and biochemical stereoselectivity of sigma opiate/PCP receptors. Brain Res. 294: 174-177. 